\title{
Sources of Self-Efficacy in Teachers
}

\author{
Fuentes de autoeficacia en profesores
}

\begin{abstract}
Karla Cristina Furtado Nina, Edson Marco Leal Soares Ramos, Maély Ferreira Holanda Ramos, Simone
Souza da Costa Silva, Ana Patricia de Oliveira Fernandez, \& Fernando Augusto Ramos Pontes
\end{abstract}

Universidad Federal de Pará, Belém, Brazil

\begin{abstract}
Teacher's self-efficacy is the judgment that teachers make about their own ability and skills in teaching, even in unfavorable conditions. A teacher's sense of efficacy can be influenced by four sources of information: mastery experience, vicarious experience, verbal or social persuasion, and emotional and physiological factors. This study aims to characterize basic education teachers, considering the indexes of the self-efficacy sources, sociodemographic aspects (like age, sex and education level of teachers), and teaching activity (working time and period of time). A total of 495 basic education teachers, who work in a private confessional network of schools in the states of Pará, Maranhão and Amapá (Brazil) participated in this study, from January to July 2014. As data collection, researchers used the Participant Characterization Survey (Questionário de Caracterização do Participante) and the Teacher Self-Efficacy Sources Scale (Escala de Fontes de Autoeficácia de Docentes). The statistical techniques used were factorial analysis and correspondence analysis. The results indicated that there was a significant association among the four sources of self-efficacy. There was a correlation between verbal persuasion and length of service and function. From the sociodemographic characteristics investigated, only age has been correlated to emotional and physiological factors. There was no association between age and the others sources.
\end{abstract}

Keywords: self-efficacy, self-efficacy sources, basic education teachers.
Resumen: La autoeficacia docente es la opinión que los profesores tienen sobre su propia capacidad y habilidades de enseñanza, aún en condiciones no favorables. Está constituida a través de cuatro fuentes de información: experiencia de dominio, experiencia vicaria, persuasión verbal o social, y estados afectivos y fisiológicos. Este estudio tuvo como objetivo caracterizar docentes de educación básica, considerando los índices de las fuentes de autoeficacia, los aspectos sociodemográficos (como edad, sexo y el nivel de educación de los profesores) y actividad docente (tiempo de trabajo y periodo de trabajo). Participaron en esta investigación 495 profesores de una red privada de escuelas confesionales de educación básica, en los estados de Pará, Maranhão y Amapá (Brasil), en el periodo de enero a julio del 2014. Para la recolección de los datos, fueron utilizados el Cuestionario de Caracterización del Participante (Questionário de caracterização do Participante) y la Escala de Fuentes de Autoeficacia Docente (Escala de Fontes de Autoeficácia de Docentes). Las técnicas estadísticas utilizadas fueron análisis factorial y análisis de correspondencia. Los resultados indicaron que hubo asociación significativa entre las cuatro fuentes de autoeficacia. Hubo correlación entre la persuasión verbal y la duración del servicio y función. De los aspectos sociodemográficos investigados, solo la edad fue correlacionada a los estados afectivos y fisiológicos. No hubo asociación de la edad con las demás fuentes.

Palabras clave: autoeficacia, fuentes de autoeficacia, profesores de educación básica.

Contact: K. C. Furtado Nina. Trav. Apinagés, 569, Edifício Valência, apartamento 1001. Bairro Batista Campos. CEP:66033-170. Email: furtadokarla@ hotmail.com

How to cite: Furtado Nina, K. C., Ramos, E. M. L. S., Holanda Ramos, M. F., Silva, S. S. da C., de Oliveira Fernandez, A. P., \& Ramos Pontes, F. A. (2016). Sources of Self-Efficacy in Teachers. Revista de Psicología, 25(1), 1-20.

http://dx.doi.org/10.5354/0719-0581.2016.42685 


\section{Introduction}

Self-efficacy is found among the main concepts formulated by Albert Bandura in his social cognitive theory (Bandura, 1977, 1986, 1997). From his perspective, the perceived self-efficacy refers to someone's beliefs in their own capacity of organizing and executing actions required to make achievements.

In the scope of teaching, the first studies that were deeply researched by Bandura appeared in the mid-1980s and ever since then, evidence of self-efficacy as a predictor of teachers' behavior has been notorious (Bzuneck, 1996; TschannenMoran, Hoy, \& Hoy, 1998). Educational psychologists and educators have studied teacher's self-efficacy since the pioneering work done by Bandura (1977).

According to the research reported by Tschannen-Moran et al. (1998), teachers that have a high level of belief in their selfefficacy are open to new ideas and are more sensitive to the search of new teaching methods as a way to find more efficient approaches for student learning. Similarly, they are less critical when facing students' mistakes and more engaged in helping them to overcome their difficulties.

Despite the existence of research attesting to the predictive power of self-efficacy in teaching practices, few studies have investigated the underlying sources of teachers' self-beliefs (Klassen, Tze, Betts, \& Gordon, 2010). Bandura (1977, 1997) proposed that the constitution of selfefficacy belief happens from the interpretations and meaning attributed to information, coming from the interaction of the individual with the environment. In other words, it comes from their experiences as well as their own and other people's achievements. Bandura identified that beliefs are built during a lifetime through four main sources: mastery experiences, vicarious experiences, verbal or social persuasion, and physiological and emotional factors.

In the mid-1990s, the first studies about self-efficacy sources were mainly performed through quantitative research (Usher \& Pajares, 2008). According to Bandura (1997), teachers make judgments of self-efficacy based on the perceptions of past teaching experiences (mastery experiences); the success or failure of other teachers, who serve as models (vicarious experiences); the verbal stimulation present in their work environment, such as that from colleagues, educational technicians and principals (verbal persuasion); and the emotional and physiological level of excitement experienced in teaching practice (affective and physiological factors).

It is important to emphasize that selfefficacy information sources are not only related to personal assessment of competence. In interpreting the results of their work, teachers acquire information on which to base their judgments. The types of generated information are used to judge the level of self-efficacy (Pajares \& Olaz, 2008).

Although there is research attesting to the predictive power of self-efficacy in teaching practice, there are few studies investigating the underlying sources of these teacher's self-beliefs (Klassen, Tze et al., 2010). The literature on the sources of teacher self-efficacy has some gaps that need to be addressed, such as the insufficient number of studies, the need for instruments which have more reliability and validity (Usher \& Pajares, 2008), and the need for a qualitative approach of investigation (Klassen, Tze et al., 2010). Im- 
provement in these areas can contribute to an understanding, not only of what the sources of influence are, but also of how they are perceived and interpreted in the judgment that the teacher makes about their ability to teach (Iaochite \& Azzi, 2012; Tschannen-Moran et al., 1998). And yet, Henson (2002) has called for more research to examine the validity and potential impact of information sources on teacher self-efficacy, noting that such surveys are almost nonexistent.

In this way, the present study aimed to analyze a group of teachers, based on the indexes of the four sources of selfefficacy, sociodemographic aspects, and teacher's activity.

\section{Method}

This is an empirical, quantitative, descriptive and inferential study performed in 2014, with teachers of basic education from a private and confessional school system.

\section{Population and Sample}

The sample has been drawn from a population of 1,079 teachers working in a private network of 28 confessional basic education schools, distributed across the states of Pará, Amapá and Maranhão (Brazil). To improve the sampling process, the researchers considered the distribution of teachers within the states, without comparative inferences among them. Then, weights were obtained proportionally using teacher populations by state and level of education.

In this work, the sampling error was initially set at $5 \%$. As in other research involving education and psychology fields, the maximum sampling error suggested by Bolfarine and Bussab (2005) is 5\%.
After obtaining the sample size, survey participants were randomly selected. In the case of teachers who did not agree to participate, a new drawing was held for the inclusion of other participants. Thus, the final sample of 495 teachers was determined, keeping in mind that some teachers were drawn into the application of the reserve questionnaire. The sampling error was reduced to $3.3 \%$.

\section{Instruments}

Two instruments already validated in Brazil were used for the data collection:

Participant Characterization Survey (Questionário de Caracterização do Participante; Guerreiro-Casanova, 2013). This survey comprised 15 items which requested data about the characteristics of the participants, such as teaching experience, number of students per class, work commute, facility infrastructure, age, sex, etcetera.

Teacher Self-Efficacy Sources Scale (Escala de Fontes de Autoeficácia de Docentes; Iaochite \& Azzi, 2012). This scale comprised 16 items distributed in intervals from 1 to 6 (1 totally false and 6 totally true), organized as follows: a) items 5, 10, 12 and 13; referring to mastery experiences; b) items 1,2 and 6 ; referring to vicarious experiences; c) Items $3,11,14$ and 15; referring to social persuasion; and d) items 4, 7, 8, 9 and 16; referring to emotional and physiological factors.

\section{Data Collection and Ethical Consider- ations}

This study has been authorized by the general coordination of private and denominational school network of the three states, and approved by the Ethics Com- 
mittee on Human Research of Tropical Medicine Center, with the protocol number 766.978. Teachers who agreed to participate signed a consent form.

The data collection process was conducted in sessions previously scheduled in each state. However, it is worth noting that before applying, the participants were informed about the research and guidelines for completing the instruments. The collection was made as a group, as all instruments are self-administered; however, the entire process of collection was supported if the participants needed guidance and clarification.

\section{Data Analysis}

Variables of the study. For the analysis of the data, three groups of variables were considered: a) relating to teaching self-efficacy sources: domain expertise, vicarious experience, verbal persuasion, and emotional and physiological factors; b) relating to sociodemographic characteristics: age, gender, and education level; and c) regarding the teaching activity. Function time (this refers to the time the teachers have worked in the same school), service time (this refers to the time the teachers have been working in a school), education level, number, hours, and number of students.

\section{Statistical Techniques}

The statistical techniques used were Factor Analysis (FA) and Correspondence Analysis (CA).

Factor analysis. Through FA the indexes of four sources of self-efficacy were constituted (mastery experience, vicarious experience, verbal persuasion, and emotional and physiological factors) according to the following assumptions: a) normality test and identification of existence of outliers; b) correlation matrix analysis, it is considered that the correlations must have values $\geq 0.30$; c) KaiserMeyer-Olkin statistic, to indicate if there is an adequacy to FA; d) Bartlett's sphericity test; e) measure of sampling adequacy, to verify if the variables studied are appropriate to the use of FA technique; f) Kaiser criterion to determine the quantity of factors extracted, in other words, quantity of equations necessary to the building of indexes; g) varimax method, to rotate the values extracted for each value, in order to maximize the information of each element used in the construction of indexes; h) calculation of factor scores (indexes) of each teacher, from the multiplication of individual values attributed to each question (items from self-efficacy scale), by teacher for factor weights; and i) standardization of the values obtained, for they could be evaluated in a scale from 0 to 1 or $0 \%$ to $100 \%$ (Fávero, Belfiore, da Silva, \& Chan, 2009).

It is observed that in all these phases the variables in the investigation showed to be adequate to FA, being possible to calculate every index. It is important to highlight that only indexes of four selfefficacy sources were made (mastery experience, vicarious experience, verbal persuasion, and emotional and physiological factors).

Teachers' classification: Indexes of teacher self-efficacy (four sources). After obtaining the standard factor scores of each teacher for the four indexes, referring to self-efficacy sources, a classification of teachers was performed in five different groups. The classification was based in the sampling percentiles theory 
(Bussab \& Morettin, 2013). So, the group of values of standard scores of each one of the indexes was divided as follows: a) Group 1, teachers with scores from $0 \%$ to $50 \%$; b) Group 2, teachers with scores from $51 \%$ to $70 \%$; c) Group 3, teachers with scores from $71 \%$ to $80 \%$; d) Group 4 , teachers with scores from $81 \%$ to $90 \%$; and e) Group 5, teachers with scores from $91 \%$ to $100 \%$. For purposes of presentation and interpretation of data, the following was considered: low scores/low degree of importance $=0 \%$ to $50 \%$; moderate scores/moderate degree of importance $=51 \%$ to $70 \%, 71 \%$ to $80 \%$, and $81 \%$ to $90 \%$; high scores/high degree of importance $=91 \%$ to $100 \%$. After the application of FA, the CA was performed.

Correspondence analysis. The purpose of using CA was to find and characterize groups (clusters) considering the factor scores of the participants in relation to the variables investigated.

The following steps to CA were considered: a) Chi-square test $\left(\chi^{2}\right)$, to verify the existence of dependence between the variables under study; b) calculation of Beta Criterion $(\beta)$, to check the dependence between the categories of variables; $c$ ) calculation of the percentage of inertia, referring to the variance explained by each dimension; and d) calculation of reliability coefficient $(\gamma)$, to know what is the probability of one variable category being associated with another. Therefore, we used a procedure based on waste, which considers the difference between the expected and the observed frequency (Ramos, Almeida, \& Araújo, 2008). The associations between categories were considered significant when the value of the reliability coefficient was $\gamma \geq 70 \%$.
The CA was performed with the help of Statistica, version 6.0 (Dell Software, 2001); and SPSS software, version 20.0, was used to perform the FA.

\section{Results}

\section{Association Between the Four Sources of Self-efficacy}

In this regard, the data referring to the application of CA in the four sources of self-efficacy is presented: mastery experience, vicarious experience, verbal persuasion, and emotional and physiological factors. All the values of the descriptive level $(p)$ were lower than those of the meaning level, namely .05 (5\%), and the scores referring to $\beta$ were higher than 3 , indicating that both indexes and their categories are dependent. Furthermore, the sum of the percentage of inertia indicated that $\mathrm{CA}$ restituted more than $70 \%$ of information. In this way, all the assumptions for the use of the CA technique were satisfied.

Afterwards, the leavings and levels of reliability applied to the indexes of the four sources of self-efficacy were calculated, which are presented in percentage maps. It is stressed that there was a significant association between the four sources of self-efficacy.

The results indicated that teachers with low and moderate scores in mastery experience had low scores in vicarious experience as well. Consequently, the group of teachers that reached moderate and high scores in mastery experience obtained the same results in vicarious experience (figure 1). 


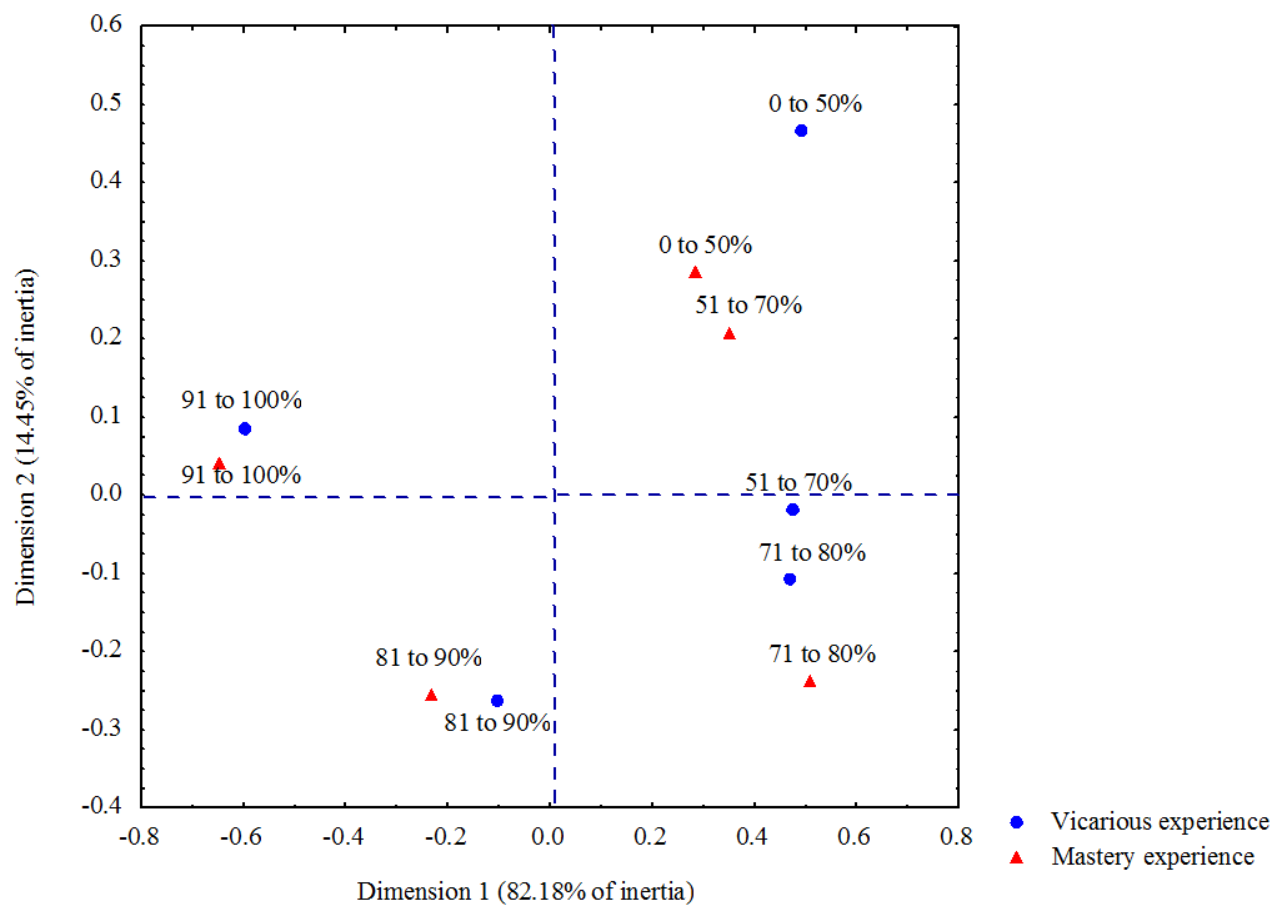

Figure 1. Perceptual map resulting from the CA applied to the mastery experience and vicarious experience indexes.

After verifying the correlation between the index of mastery experience and the index of vicarious experience, the evalua- tion of the association between mastery experience and verbal persuasion indexes (figure 2) was performed.

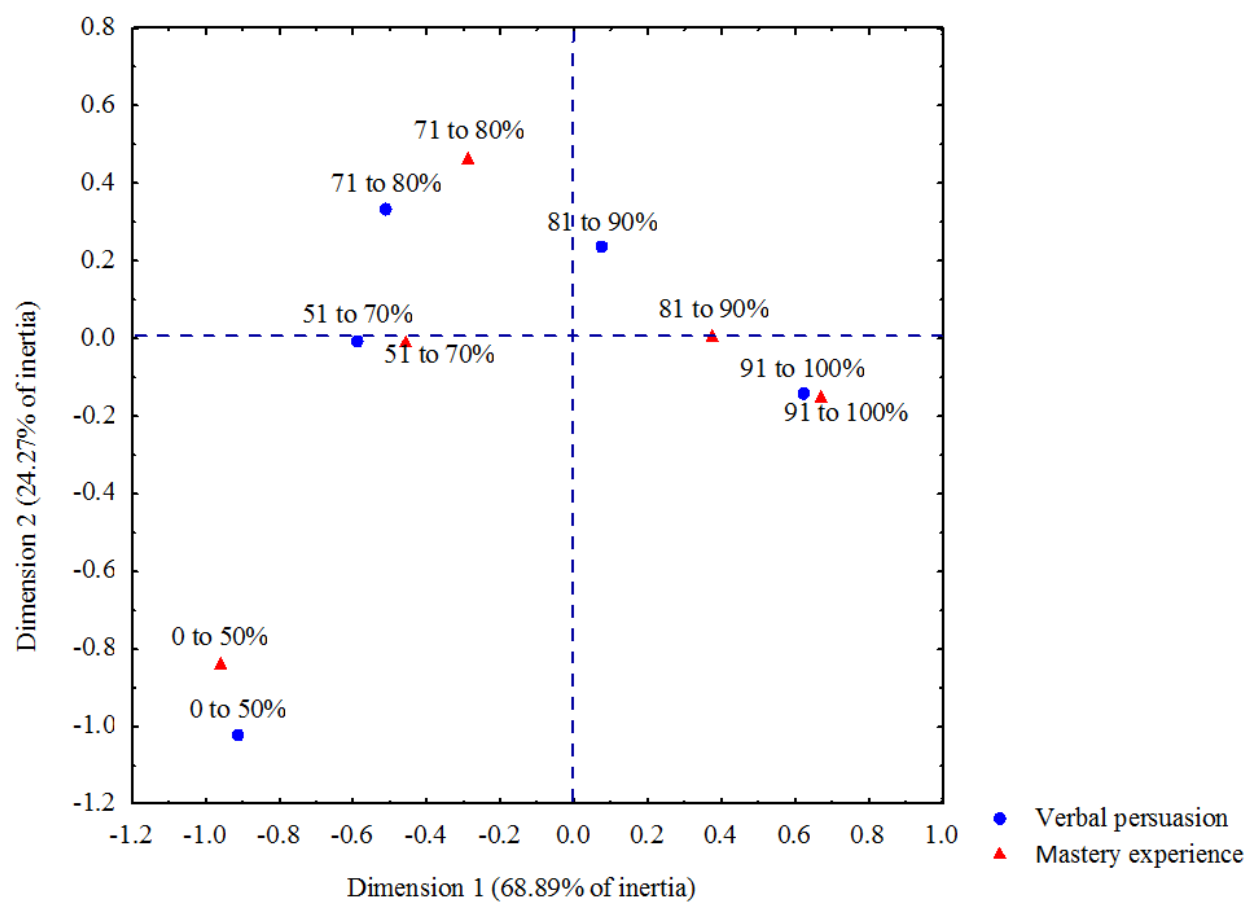

Figure 2. Perceptual map resulting from the CA applied to the mastery experience and verbal persuasion indexes. 
Figure 2 represents the groups of teachers structured as follows: Teachers having low and moderate scores in mastery experiences also had the same scores in verbal persuasion; and teachers reaching moderate and high scores in mastery experiences had the same values in verbal persuasion.

After the verification of correlation between mastery experience and verbal persuasion indexes, the calculation of the association between mastery experience and emotional and physiological factors (figure 3) was made.
The results on figure 3 indicate that the group of teachers which obtained the lowest scores in emotional and physiological factors obtained low and moderate values in mastery experiences as well. On the other hand, the teachers who reached the highest scores in mastery experiences had moderate and high scores in emotional and physiological factors. Following this, the evaluation of the association between vicarious experience and verbal persuasion indexes (figure 4) was performed.

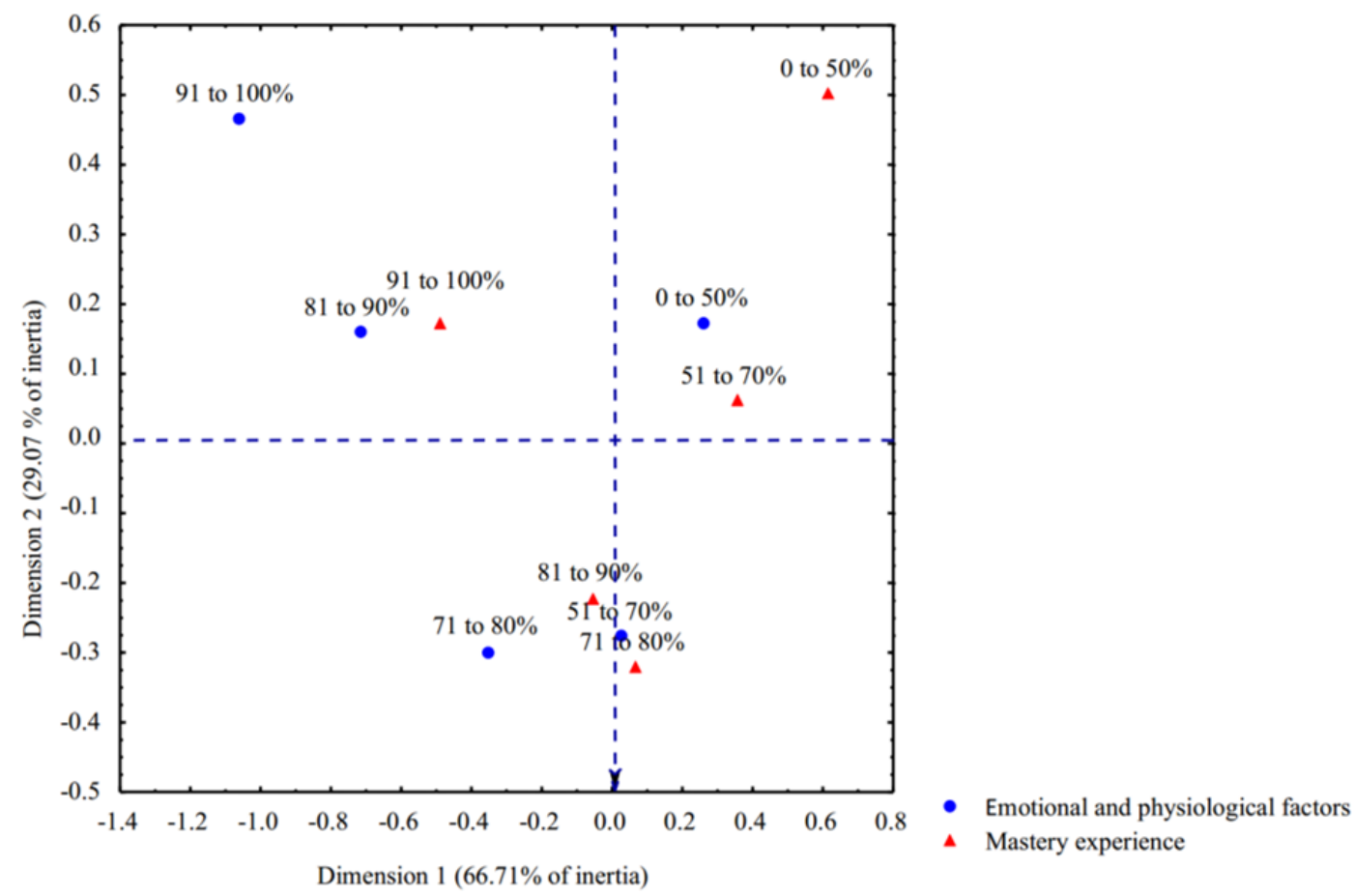

Figure 3. Perceptual map resulting from the CA applied to the mastery experience and emotional and physiological factors indexes. 


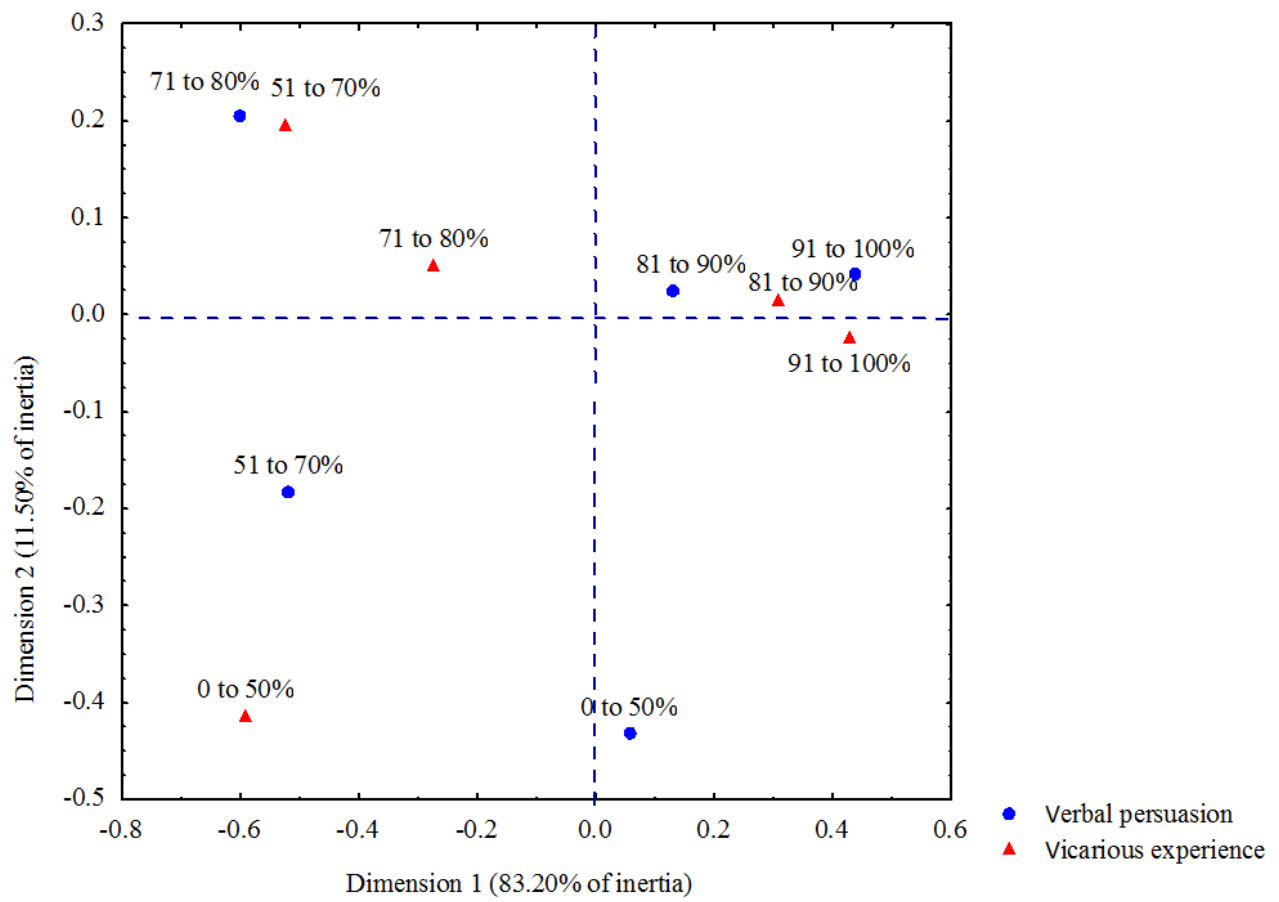

Figure 4. Perceptual map resulting from the CA applied to the vicarious experience and verbal persuasion indexes.

Figure 4 shows that the group of teachers with low scores in verbal persuasion obtained the highest values in vicarious experience. Furthermore, teachers with the lowest scores in vicarious experiences reached moderate levels in verbal persuasion, and teachers with moderate scores in vicarious experiences reached moderate and high percentages in verbal persuasion. Other teachers that reached moderate scores in vicarious experience had also moderate percentages in verbal persuasion. Subsequently, the association between the vicarious experience and emotional and physiological factors indexes was evaluated (figure 5).
Figure 5 indicates that teachers with low percentages in vicarious experience obtained low and moderate scores in emotional and physiological factors. On the other hand, teachers with higher scores in vicarious experience obtained moderate scores in emotional and physiological factors. Furthermore, teachers that had moderate scores in emotional and physiological factors had the same result in vicarious experience. Afterwards, the association between verbal persuasion and emotional and physiological factors indexes was calculated (figure 6). 


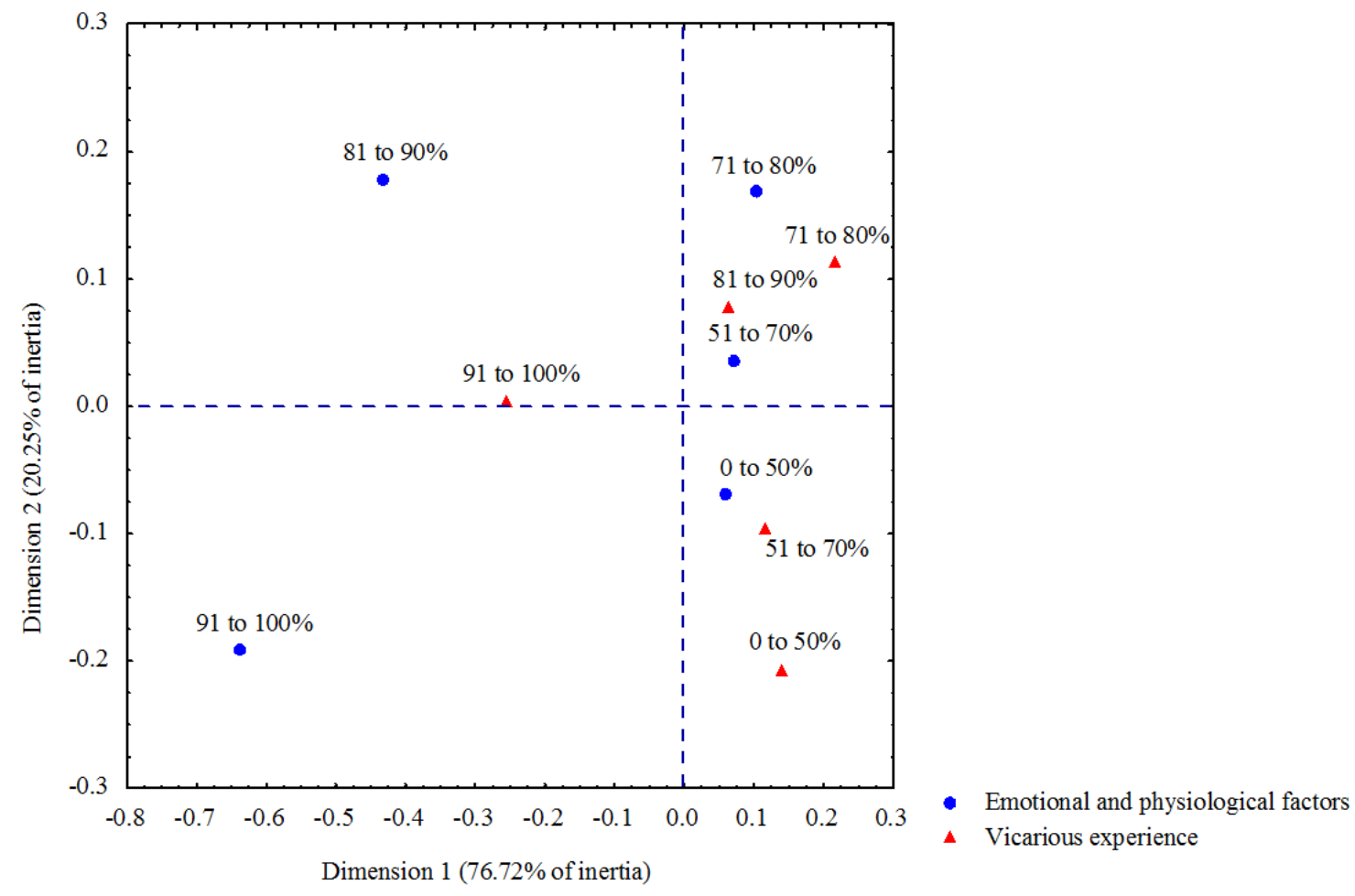

Figure 5. Perceptual map resulting from the CA applied to the vicarious experience and emotional and physiological factors indexes.

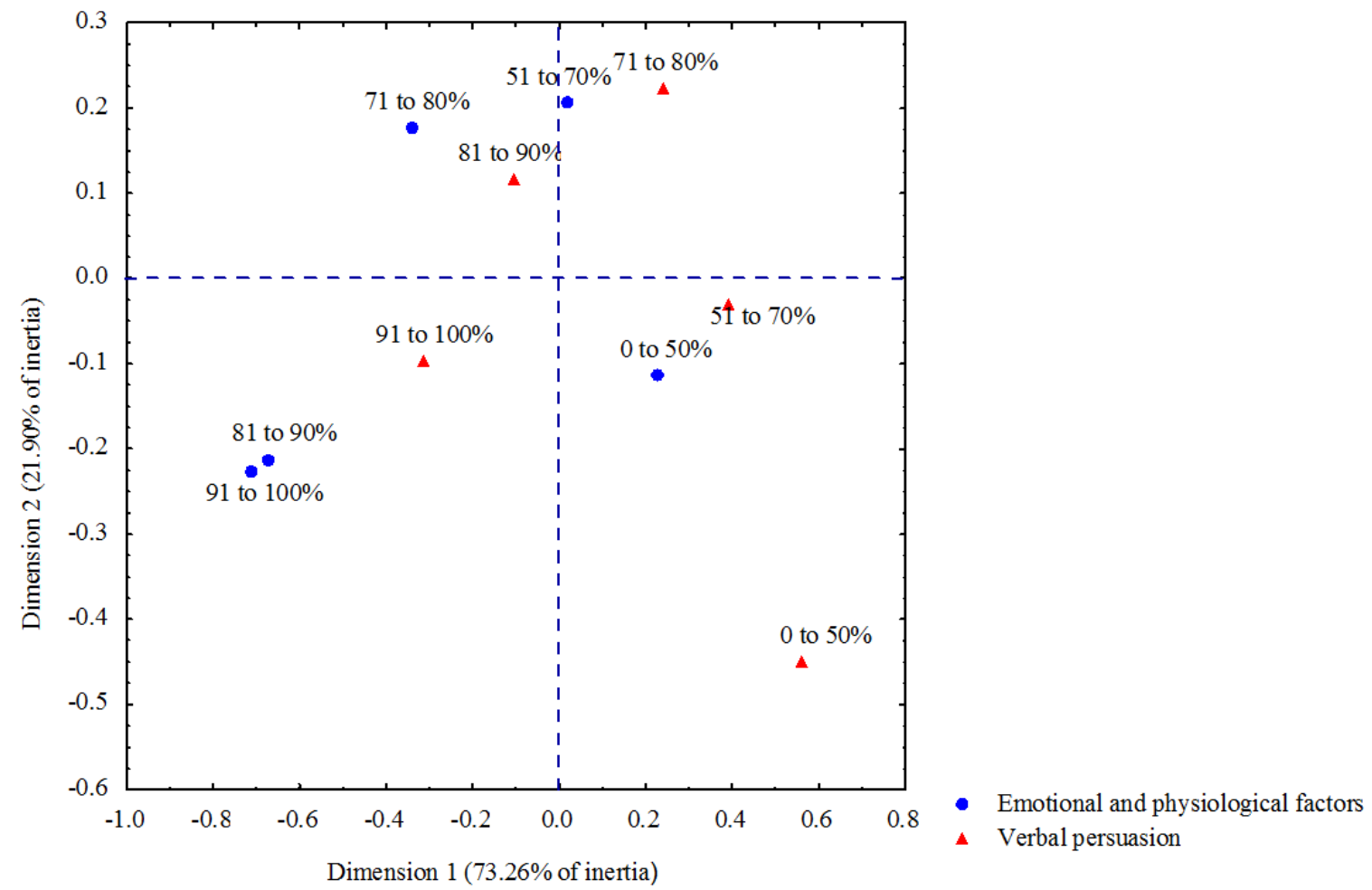

Figure 6. Perceptual map resulting from the CA applied to the verbal persuasion and emotional and physiological factors indexes. 
The results on figure 6 reveal that the group of teachers that obtained low scores in emotional and physiological factors had also low and moderate scores in verbal persuasion. On the other hand, the teachers with higher scores in verbal persuasion had high and moderate scores in emotional and physiological factors as well. Furthermore, the teachers that had moderate scores in emotional and physiological factors had also moderate scores in verbal persuasion.

\section{Self-Efficacy Sources: Sociodemo- graphic Aspects and Teacher Activity}

In this section, the data referring to the application of the CA of the four sources of self-efficacy related to the variables connected to sociodemographic aspects and to the teachers' activity is presented.

There was no statistical difference between the indexes mastery experience and vicarious experience considering time of function, education level, year, education degree, age, sex, time of service, workload, nor number of students/class (all $p \mathrm{~s}>.05$ ).

In the same lines, there was no statistical difference between the verbal persuasion index and education level, year, education degree, age, sex, workload, nor number of students/class (all $p \mathrm{~s}>.05$ ). Furthermore, there was no statistical difference between the emotional and physiological factors index and state, education level, year, post-graduate studies, sex, time of service, workload, nor number of students/class (all $p \mathrm{~s}>.05$ ).

The association between the verbal persuasion index and the variables of time of function and time of service were significant $(p<.05)$. There was also a statistical difference between emotional and physiological factors and the variable of age.

Consequently, the residual and reliability levels applied to the referred indexes were calculated from two sources of selfefficacy (verbal persuasion and emotional and physiological factors), and the variables referring to sociodemographic aspects and teachers' activity, among which only the ones presenting significant association with the aforementioned sources: years in the function and years of service; age (respectively) were detected. Such leavings are presented in probability percentage (see table 1).

The group of teachers that had the lowest scores in verbal persuasion presented the following characteristics: a) time of function and time of service shorter than a year, and b) 21 to 30 years of time of function and service.

The teachers that obtained moderate scores in verbal persuasion had the following profile: a) less than a year of time of function and service, b) 11 to 15 years of time of function and service, and c) within 21 and 25 years of time of service.

The teachers who obtained the highest scores in verbal persuasion presented the following aspects: a) 5 to 10 years of time of function and service, and b) 16 to 20 years of time of service. The leavings and reliability levels resulting from the CA, which was applied to the emotional and physiological factors index and age, were presented in probability percentages (see table 2). 
Table 1

Correspondence Analysis Applied to the Verbal Persuasion Index, Time of Function and Time of Service.

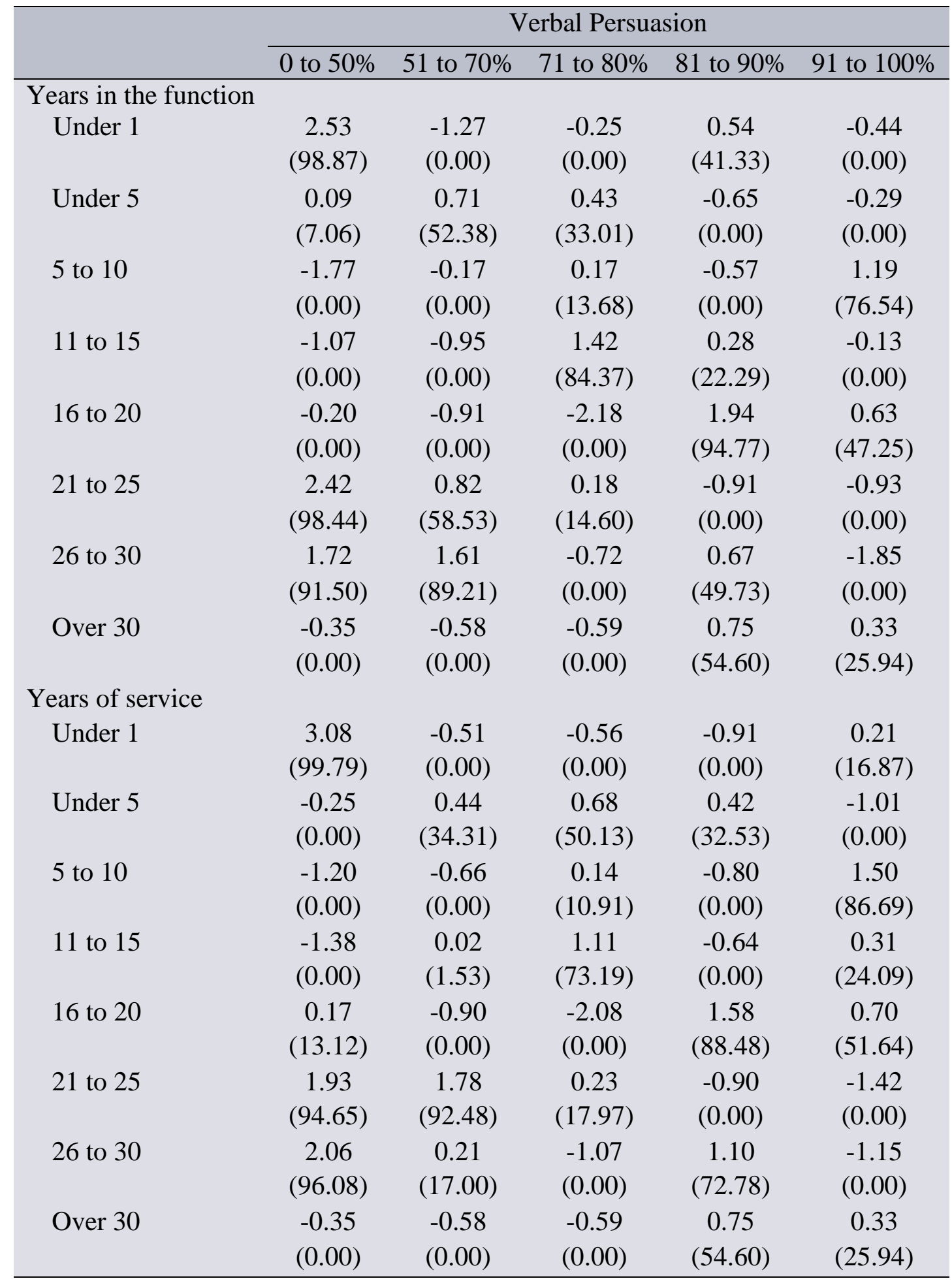

Note: Leavings and confidence levels (between parenthesis). Values above $50 \%$ are significantly associated. 
Table 2

Correspondence Analysis Applied to the Emotional and Physiological States

Index and Age.

\begin{tabular}{cccccc}
\hline & \multicolumn{5}{c}{ Emotional and physiological states } \\
\cline { 2 - 6 } Years of age & 0 to $50 \%$ & 51 to $70 \%$ & 71 to $80 \%$ & 81 to $90 \%$ & 91 to $100 \%$ \\
Under 20 & -0.98 & 1.78 & -0.44 & -0.29 & -0.39 \\
& $(0.00)$ & $(92.48)$ & $(0.00)$ & $(0.00)$ & $(0.00)$ \\
20 to 27 & 1.00 & -0.47 & -0.68 & 0.98 & -1.55 \\
& $(68.47)$ & $(0.00)$ & $(0.00)$ & $(67.48)$ & $(0.00)$ \\
28 to 35 & -1.93 & 1.80 & -0.21 & 0.67 & 0.99 \\
& $(0.00)$ & $(92.81)$ & $(0.00)$ & $(49.48)$ & $(67.56)$ \\
36 to 44 & 0.80 & -1.29 & 0.12 & -0.88 & 1.10 \\
& $(57.58)$ & $(0.00)$ & $(9.78)$ & $(0.00)$ & $(72.89)$ \\
45 to 52 & 1.65 & -1.41 & 0.89 & -1.58 & -1.15 \\
& $(90.04)$ & $(0.00)$ & $(62.85)$ & $(0.00)$ & $(0.00)$ \\
Over 52 & -1.15 & 0.70 & 0.75 & 0.69 & 0.11 \\
& $(0.00)$ & $(51.61)$ & $(54.38)$ & $(50.86)$ & $(8.66)$ \\
\hline
\end{tabular}

Note: Leavings and confidence Levels (between parenthesis). Values above $50 \%$ are significantly associated.

It is highlighted that only the variable age was significantly associated with the emotional and physiological factors, and was not correlated to any other source of information. The group of teachers with the lowest scores in emotional and physiological factors is found in the following age groups: a) 20 to 27 , and b) 36 to 52 .

Teachers with moderate scores in emotional and physiological factors are the ones found in the following age groups: a) Under 20 years old, b) 20 to 35 years old, and c) 45 to 52 years old.

The group of teachers with the highest scores in emotional and physiological factors had ages between 28 and 44 years old.

\section{Discussion}

The results of this study were discussed in-depth in relation to the social cognitive theory, specifically, in the sources of self- efficacy proposed by Bandura (1977, 1997); and to studies already performed about this subject (Iaochite \& Azzi, 2012; Palmer 2011; Tschannen-Morann \& Johnson, 2011; Usher \& Pajares, 2008; Uzuntiryaki, 2008).

The results from the present research analyzed the associations established among the four sources of self-efficacy, sociodemographic variables and teaching activity. All four sources were correlated amongst each other; however, there was no association between the sources of mastery experience and vicarious experience with the sociodemographic variables, nor the ones related to teaching activity listed in this research. Verbal persuasion was correlated to only two variables, namely: time of function and service. The source of emotional and physiological factors was associated only to age. This demonstrates that in the sample, most of the sociodemographic varia- 
bles were considered, and the ones related to teaching activity were not related to the sources of self-efficacy.

Because it was a confessional school system, it is possible that other variables emerging in this context might be more related to the sources, for example, religion. It is considered, due to its religious environment, that the teachers' religion might have some effect on the sources; however, in the present research it was not possible to evaluate the association between the sources and the teachers' religion.

By means of the observation of the teachers' population profile in this study, and based on the data of characteristics provided by the managers of the school system at Pará, Amapá and Maranhão, it was noticed that $83 \%$ of the teachers composing this population $(1,079)$ claimed to have the same religion that the school system has. Only 17\% belong to other religious beliefs. It was not possible to measure this data in the considered population sample; however, it is understood that the religious aspects of the teachers who participated in this research are important and might be associated to the self-efficacy information sources.

It is considered that religious experience might influence the perception of teachers. A Catholic does not make a judgment on circumstances based on the same criteria used by a Protestant or an Umbandista, for example. In this way, religious principles influence the way that individuals interpret every fact related to them (Cavaliere, 2007). In the case of institutions that are religious, as it happens with the school system participating in this research, this religious profile might influence the administrative and pedagogic structure of the institutions (Marcondes, Menslin, Ribeiro, \& Jun- queira, 2005). Therefore, teachers, even those having a different religion from the one professed by the school, pass through a process of institutionalization that might also influence the interpretation of information sources and, consequently, the constitution of their beliefs of efficacy.

\section{Association Between the Four Sources of Self-Efficacy}

The results have revealed that there was a significant association between the four sources of self-efficacy, which indicates the probability of them being correlated, which means that if a variable (source) changes the other will also change, because they covary (Dancey \& Reidy, 2006). When something in one of the sources changed, this also reflected in the other sources, or approximately thereof, so that the data indicated that teachers presenting low scores in a certain source also obtained low or moderate scores in the other sources. The same situation happened when teachers presented high scores.

In general, the correlation among the four sources followed the same -or approximately the same- direction. When, for example, a group of teachers presented low scores in a source of information, they obtained low or moderate scores in other ones. It was noticed, however, that there was an exception in the case of the association between verbal persuasion and vicarious experience. Teachers placing little importance to verbal persuasion attributed elevated relevance to vicarious experience. This data is confirmed in the literature, where it is possible to find studies indicating that the vicarious experience was more relevant than verbal persuasion in teachers' routines and in the constitution of efficacy beliefs (Atay, 2007; Aydin, Demirdöğen \& Tarkin, 2012). 
The association among the four sources is consistent with the explanations of Bandura (1997), referring to significant correlations between sources. For the author, it is necessary to understand that the information provided by one or more sources is cognitively evaluated by the individual and, therefore, depends on the weight (value) attributed to each source through self-reflective processes; keeping in mind that the self-efficacy sources are integrated with one another in different ways (Iaochite \& Azzi, 2012).

All the sources interact and the role of each one in the building of people's sense of efficacy is diverse and interdependent with environmental conditions and the behavioral history of each individual. This is consistent with the principle of triadic reciprocity (mutual influence of individual, environmental and behavioral factors) that is the base of the social cognitive theory (Azzi, Polydoro, \& Maciel, 2005). Iaochite and Azzi (2012) identifies relationships between sources in a study of validation of the scale of sources of teachers' self-efficacy, in which all correlations were positive and meaningful, however, the values of correlations alternated between low $(r=.11)$ and moderate $(r=.44)$.

The Importance of Verbal Persuasion for Novice or Beginner Teachers

It is highlighted that novice or beginner teachers, with time of service and time of function shorter than a year, attributed low or moderate importance to verbal persuasion in the performance of teaching activities.

This result draws attention, because it is known from literature that beginner teachers frequently search for step by step instructions of how to perform their task of teaching. They want to learn how to manage the class, how to organize the curriculum, how to evaluate students, and how to manage groups (Garcia, 2010).

Ultimately, supportive words are necessary in the process of learning the teaching task. Optimistic phrases stimulate and inspire the teacher to direct his/her work. For beginner teachers, relevant feedback from students comes in the form of stimulation and engagement, and verbal persuasion from experienced teachers takes the form of guidance, encouragement and advice (Mulholland \& Wallace, 2001). Thus, this source has obvious importance for teachers beginning their careers.

Supporting this idea, Tschannen-Moran and Hoy (2007), for example, evidenced the value of verbal or social persuasion for novice teachers in a sample composed of 255 teachers from three state universities, two in Ohio and one in Virginia, as well as volunteer teachers from two primary schools and a secondary school in the same states. This study demonstrated that, in comparison to teachers with more established careers, self-efficacy of beginner teachers seems to be more influenced by verbal persuasion.

It is important to stress that beginner teachers need guidance in the teaching practice, so they can improve continuously as teachers (Garcia, 2010). This becomes more possible when verbal or social persuasion occurs with greater frequency, given that the uncertainty about the capacity of teaching, arising from their inexperience, is frequently complemented with the reinforcement from other significant peers (Martins, Onofre, \& Costa, 2014). 


\section{Verbal Persuasion on Experienced Teachers}

In the present research, teachers that obtained the highest scores in verbal persuasion had between 5 to 10 years of time in the function and service, and 16 to 20 years of time of service, showing to have experience as professionals.

These results differ from the ones postulated in the literature, because it is common in the studies that mastery experiences are presented as the most important source for experienced teachers, while verbal persuasion shows to be of more importance to novice teachers (Hoy \& Spero, 2005; Klassen \& Chiu, 2010; Tschannen-Moran \& Hoy, 2007).

Martin, McCaughtry, Kulinna and Cothran (2009) performed a study with 47 teachers of physical education during a continuing training course through an intervention with teachers. The results showed that the tips and guidance concerning the use of new teaching strategies made the participants feel more secure of their ability to apply new knowledge in their classes. These results reinforce the idea that social persuasion, when done in favorable conditions, contributes to elevate the perception of the teacher's capacity to teach for both new and experienced teachers (da Costa Filho, 2014).

The present study also identified that teachers with more than 20 years of time of function and service (21 to 30 years), attributed less importance to verbal persuasion. It is considered that these teachers are at the end of their career and, perhaps for that reason, verbal persuasion does not reach the elevated degree of importance equivalent to the results of the other experienced teachers (5 to 10 years and 16 to 20 years).
Relationship Between Age and Emotional and Physiological Factors

The results of the present study indicate that emotional and physiological factors seem to be important for teachers from different age groups, that is, teachers with ages between 28 and 44 years old.

However, although emotional and physiological factors seem to be important for teachers from different age groups in the sample of this study, in the literature they are presented as a source of information with less influence over the efficacy of teaching (Bandura, 1997; Mulholland \& Wallace, 2001). They are regarded as the less valued source (Martins et al., 2014). Kooij, de Lange, Jansen and Dikkers (2008) suggest that physical and psychological factors related to age might influence the motivation at work.

Mulholland and Wallace (2001) in their studies about self-efficacy in the teaching of sciences noticed that emotional and physiological factors do not seem as important as other sources of information. The same happened in a study by Aydin et al. (2012), in which they aimed to identify the sources of self-efficacy applied to a teaching task and their influence on teaching, during a semester long preservice internship for chemistry teachers. The results indicated that emotional and physiological factors, contrary to other sources, did not influence teachers training in pre-service.

Emotional and physiological factors might positively influence teachers' work when perceived and experienced in a positive manner, for example, when a teacher is in a good mood, vigilant and serene. In this way, the teacher interprets these factors as indications of preparation and capacity. However, when they experience 
negative sensations, like anxiety, fear and pain, the individuals might see themselves as less capable (Bandura, 1997).

It is possible to see that a great part of the results presented in this study, which involves the association between the four sources of information, sociodemographic factors and aspects related to teaching activity, diverge from previous research. Specifically, the level of importance of verbal persuasion for experienced teachers and the low or moderate importance of verbal persuasion for novice or beginner teachers were, contrary to the data, already presented in the existing literature (Aydin et al., 2012; Bandura, 1997; Hoy \& Spero, 2005; Klassen, Usher, \& Bong, 2010; Mulholland \& Wallace, 2001; TschannenMoran \& Hoy, 2007). This might relate to the religious conception of teachers; however, as mentioned previously, it was not possible to confirm this, as this aspect was not explored in this study.

\section{Final Considerations}

This research makes a valuable contribution to the social cognitive theory, specifically in the field of studies about selfefficacy sources in the scope of teaching basic education. In a specific way, it expands the knowledge about the influence of certain variables, such as sociodemographic aspects and teaching activities.

The association among the four sources of self-efficacy was highlighted in the results of this study. When comparing the data with the literature, it was noticed that the processing of information provided from one or several sources is the result of self-reflection performed by an individual during the teaching practice. It is considered that identifying the origin of information, in other words, the source, is just as important as it is to understand how individuals evaluate and integrate this information, which will contribute to the establishment of self-efficacy beliefs.

In this study the aim was to investigate the relationship between different sociodemographic factors and variables related to teaching activity with self-efficacy sources. It is stressed that the sources of mastery experience and vicarious experience were not correlated to any of the contextual variables in the study. It was noticed, however, that verbal persuasion is associated to time of function and service of teachers, and that emotional and physiological factors relate to teachers' age. It is worth noting that the research exploring these relationships in teachers' samples is recent and still scarce, making additional studies necessary to amplify further the understanding of these aspects. In this sense, the present study represents an important expansion of the possibilities of research in this field.

It is worth highlighting as well, that the results presented here are limited to the context of the research, number of participants and method of analysis employed by the researcher. These results might serve as a base to think over the routine of teachers and the aspects that affect the process of teaching and learning.

One limitation of this work is the absence of data about teachers' religion. It was not possible to collect information on this subject; however, it is known that such issue has great importance, because since these schools are openly religious, the religious beliefs of teachers and even the process of institutionalization of these schools might be related to the way individuals interpret sources of information and how efficacy beliefs are constituted. 
Future research might investigate the relationship between religious beliefs of teachers and their beliefs of efficacy.

Besides this aspect, it is suggested that future research focuses on other factors, for example, aspects related to teaching context (infrastructure, quantity of pedagogical material, and technological equipment), continuing training and salary, which might be associated to selfefficacy sources.

\section{References}

Atay, D. (2007). Beginning teacher efficacy and the practicum in an EFL context. Teacher Development, 11(2), 203-219. http://dx.doi.org/10.1080/13664530701414720

Aydin, S., Demırdöğen, B., \& Tarkin, A. (2012). Are they efficacious? Exploring preservice teachers' teaching efficacy beliefs during the practicum. Asia-Pacific Education Researcher, 21(1), 203-213. Retrieved from https://is.gd/VleI4s

Azzi, R. G., Polydoro, S. A. J., \& Maciel, A. C. (2005, May). Crenças de auto-eficácia docente: problematizando sua importância no cotidiano escolar a partir de um estudo junto a professores de línguas estrangeiras. In Congresso Internacional Educação e Trabalho: Representações Sociais, Competências e Trajectórias Profissionais, Aveiro, Portugal. Retrieved from https://is.gd/A3iVUt

Bandura, A. (1977). Self-efficacy: Toward a unifying theory of behavioral change. Psychological Review, 84(2), 191-215. http://dx.doi.org/10.1037/0033-295x.84.2.191

Bandura, A. (1986). Social foundations of thought and action: A social cognitive theory. Englewood Cliffs, New Jersey: Prentice-Hall.

Bandura, A. (1997). Self-efficacy: The exercise of control. New York, New York: W.H. Freeman and Company.

Bolfarine, H. \& Bussab, W. O. (2005). Elementos de amostragem. Porto Alegre, Brasil: Bookman.

Bussab, W. de O. \& Morettin, P. A. (2013). Estatística básica. São Paulo, Brasil: Saraiva.

Bzuneck, J. A. (1996). Crenças de auto-eficácia de professoras do $1^{\circ}$. Grau e contexto. Arquivos Brasileiros de Psicologia, 48(4), 57-89. Retrieved from http://www.uky.edu/ eushe2/Pajares/Bzuneck.pdf

Cavaliere, A. M. (2007). O mal-estar do ensino religioso nas escolas públicas. Cadernos de Pesquisa, 37(131), 303-332. http://dx.doi.org/10.1590/s0100-15742007000200005 
da Costa Filho, R. A. (2014). Professores iniciantes de educação física: Discussões a partir das fontes de autoeficácia docente (Master's thesis, Universidade Estadual Paulista Júlio de Mesquita Filho, Rio Claro, Brasil). Retrieved from http://repositorio.unesp.br/bitstream/handle/11449/110422/000789246.pdf?sequence=1

Dancey, C. P. \& Reidy, J. (2006). Estatística sem matemática para psicologia: Usando SPSS para Windows. Porto Alegre, Brasil: Artmed.

Dell Software. (2001). Statistica (6.0) [Proprietary software] StatSoft.

Fávero, L. P., Belfiore, P., da Silva, F. L., \& Chan, B. L. (2009). Análise de dados: Modelagem multivariada para tomada de decisão. Rio de Janeiro, Brasil: Campus-Elsevier.

Garcia, C. M. (2010). O professor iniciante, a prática pedagógica e o sentido da experiência. Formaçao Docente, 2(3), 11-49. Retrieved from http://formacaodocente.autenticaeditora.com.br/artigo/exibir/8/18/1

Guerreiro-Casanova, D. C. (2013). Crenças de eficácia de gestores escolares e de docentes no ensino médio paulista (Doctoral dissertation, Universidade Estadual de Campinas, Campinas, Brasil). Retrieved from http://unicamp.sibi.usp.br/handle/SBURI/6114

Henson, R. K. (2002). From adolescent angst to adulthood: Substantive implications and measurement dilemmas in the development of teacher efficacy research. Educational Psychologist, 37(3), 137-150.

http://dx.doi.org/10.1207/s15326985ep3703_1

Hoy, A. W. \& Spero, R. B. (2005). Changes in teacher efficacy during the early years of teaching: A comparison of four measures. Teaching and Teacher Education, 21(4), 343356.

http://dx.doi.org/10.1016/j.tate.2005.01.007

Iaochite, R. T. \& Azzi, R. G. (2012). Escala de fontes de autoeficácia docente: Estudo exploratório com professores de educação física. Psicologia Argumento, 30(71), 659669.

http://dx.doi.org/10.7213/psicol.argum.7472

Klassen, R. M. \& Chiu, M. M. (2010). Effects on teachers' self-efficacy and job satisfaction: Teacher gender, years of experience, and job stress. Journal of Educational Psychology, 102(3), 741-756.

http://dx.doi.org/10.1037/a0019237

Klassen, R. M., Tze, V. M. C., Betts, S. M., \& Gordon, K. A. (2010). Teacher efficacy research 1998-2009: Signs of progress or unfulfilled promise? Educational Psychology Review, 23(1), 21-43.

http://dx.doi.org/10.1037/e625142010-001

Klassen, R. M., Usher, E. L., \& Bong, M. (2010). Teachers' collective efficacy, job satisfaction, and job stress in cross-cultural context. The Journal of Experimental Education, 78(4), 464-486.

http://dx.doi.org/10.1080/00220970903292975 
Kooij, D., de Lange, A., Jansen, P., \& Dikkers, J. (2008). Older workers' motivation to continue to work: Five meanings of age: A conceptual review. Journal of Managerial Psychology, 23(4), 364-394.

http://dx.doi.org/10.1108/02683940810869015

Marcondes, L. R. L., Menslin, D. J., Ribeiro, E., \& Junqueira, S. R. A. (2005, October). Educação confessional no Brasil uma perspectiva ética. In VII Congresso Nacional de Educação - EDUCERE - Edição Internacional, Curitiba, Brasil.

Martin, J. J., McCaughtry, N., Kulinna, P. H., \& Cothran, D. (2009). The impact of a social cognitive theory-based intervention on physical education teacher self-efficacy. Professional Development in Education, 35(4), 511-529. http://dx.doi.org/10.1080/19415250902781814

Martins, M., Onofre, M., \& Costa, J. (2014). Experiências de formação que tornam o futuro professor de educação física mais confiante no início do estágio. Boletim da Sociedade Portuguesa de Educação Física, 38, 27-43. Retrieved from http://www.spef.pt/image-gallery/87140544708212-Boletim-SPEF-38-Artigo-2.pdf

Mulholland, J. \& Wallace, J. (2001). Teacher induction and elementary science teaching: Enhancing self-efficacy. Teaching and Teacher Education, 17(2), 243-261. http://dx.doi.org/10.1016/s0742-051x(00)00054-8

Palmer, D. (2011). Sources of efficacy information in an inservice program for elementary teachers. Science Education, 95(4), 577-600. http://dx.doi.org/10.1002/sce.20434

Pajares, F. \& Olaz, F. (2008). A evolução da teoria social cognitiva. In A. Bandura, R. G. Azzi, \& S. Polydoro (Eds.), Teoria social cognitiva: Conceitos básicos (pp. 97-114). Porto Alegre, Brasil: Artmed.

Ramos, E. M. L. S., Almeida, S. dos S., \& Araújo, A. dos R. (2008). Segurança pública: Uma abordagem estatística e computacional. Belém, Brasil: Editora Universitaria UFPA.

Tschannen-Moran, M. \& Hoy, A. (2007). The differential antecedents of self-efficacy beliefs of novice and experienced teachers. Teaching and Teacher Education, 23(6), 944-956. http://dx.doi.org/10.1016/j.tate.2006.05.003

Tschannen-Moran, M., Hoy, A. W., \& Hoy, W. K. (1998). Teacher efficacy: Its meaning and measure. Review of Educational Research, 68(2), 202-248. http://dx.doi.org/10.3102/00346543068002202

Tschannen-Moran, M. \& Johnson, D. (2011). Exploring literacy teachers' self-efficacy beliefs: Potential sources at play. Teaching and Teacher Education, 27(4), 751-761. http://dx.doi.org/10.1016/j.tate.2010.12.005

Usher, E. L. \& Pajares, F. (2008). Sources of self-efficacy in school: Critical review of the literature and future directions. Review of Educational Research, 78(4), 751-796. http://dx.doi.org/10.3102/0034654308321456 
Uzuntiryaki, E. (2008). Exploring the sources of Turkish pre-service chemistry teachers' chemistry self-efficacy beliefs. Australian Journal of Teacher Education, 33(6), 12-28. http://dx.doi.org/10.14221/ajte.2008v33n6.2

Reception date: August 24, 2015

Acceptance date: February 8, 2016 